\title{
CORRUPTION - A DARK SIDE OF ENTREPRENEURSHIP. CORRUPTION AND INNOVATIONS
}

\section{Marek Tomaszewski*}

\begin{abstract}
In this article, corruption is treated as an expression of human entrepreneurship, which does not fully fit in the commonly accepted moral and legal standards. Despite being negatively perceived, it is persistently present in the public, economic and political life of every country as evidenced by a number of press releases on corruption.

Research literature analysis reveals the existence of two conflicting opinions with regard to the way in which corruption affects innovative activity of companies and economic growth. The more morally correct theory, which can be dubbed the sand-the-wheels theory, assumes that corruption negatively influences innovative activity and economic growth. Whereas, the grease-the-wheels theory, which is inconsistent with the principles of social responsibility of business, argues for the positive influence of corruption on innovative activity of companies and economic growth. This article is a voice in that discussion.
\end{abstract}

Keywords: corruption, entrepreneurship, the sand-the-wheels theory, the grease-the-wheels theory, innovations, economic growth

JEL Classification: O31, O32, O38, D23, D73, L26

\section{Introduction}

Corruption is a complex and contentious issue (Luo, 2005, pp. 119-120; Cosenz, Noto, 2014, pp. 239-257), which is viewed differently depending on the cultural norms prevailing in a given country (Börzel, van Hüllen, 2014, pp. 613-614). Moreover, recent research suggests that human genetic diversity may be an origin of corruption (Kunieda, Okada, Shibata, 2016, pp. 1-40). For example, in the Arabic countries, "baksheesh" comes directly from the religious Islamic guidelines and is treated as normal in economic contexts. The industrialised, democratic countries have a completely different approach to corruption. There, corruption is treated as immoral and is punishable by law. We should point out here that despite such negative and often restrictive approaches to this problem, it is, nevertheless, prevalent in social, economic and political life of these countries, as witnessed to a larger or smaller degree by the press releases (Villoria M., Van Ryzin G.G., Lavena C.F., 2012, p. 85; Zaloznaya 2014, p. 187; Rose-Ackerman, 1999; Tonoyan, Strohmeyer, Habib, Perlitz, 2010, pp. 803-831; Haque, Kneller, 2015, pp. 623-651).

* Marek Tomaszewski, Department of Innovation and Entrepreneurship, University of Zielona Gora (m.tomaszewski@wez.uz.zgora.pl). 
What is the essence of corruption? Each of us can intuitively recognise, when corruption takes place. The most popular definition says that corruption is the abuse of broadly-conceived power for private purposes (Zaloznaya 2015, p. 345, Tanzi, 1995, pp. 161-180; Rodriguez, Siegel, Hillman, Eden, 2006, pp. 733-746). One should bear in mind that corruption is not limited to the public sector but, instead, can also take place in the private sector, especially in large companies (Tanzi, 1998, p. 8).

Each instance of corruption involves the following elements: a) a corrupting agent, b) a corrupted agent, c) an object of corruption, understood as a problem, the solution to which allows the corrupted agent to be provided with a gratification (bribe), d) corruptive gratification (bribe), e) unfavourable conditions that push agents to seek alternative solutions to the problem, which becomes the object of corruption.

Putting aside the moral and legal issues, corruption can be compared to a typical market transaction, where the buyers (the corrupting agents) meet the sellers (the corrupted agents), the object of the transaction is the solution to the problem of the corrupting agent, and the price is the bribe, the exact character of which is an object of negotiation between the two parties. In such an approach, the occurrence of corruption is an indication of entrepreneurship and innovativeness. The corrupting agent, instead of acting in a standard way, seeks new, alternative solutions to the problem, which is a sign of entrepreneurship. One can even venture to say that such an action is an example of a process innovation, as it amounts to a new way of solving a problem. The corrupted agent also takes advantage of the situation, hence shows entrepreneurial spirit and, owing to the fact that the agent extends the range of services to include an "express track", he or she can be called an innovator.

When viewing corruption as a sign of entrepreneurship or even innovativeness one should bear in mind that it is also an indication, and a cause of, the weakness of the institutional environment of a company (Ugur, 2014, pp. 472-473; Shleifer, Vishny, 1993, pp. 599-617). Corruption leads to an increase in transaction costs related to the agreements made and to a decrease in trust levels among the market players (Williamson, 1991, pp. 269-96; Pillay, Kluvers, 2014, pp. 95-119).

Moreover, North (1990) and others (Ivanyna, Moumouras, Rangazas, 2016, pp. 520 542; Keig, Brouthers, Marshall, 2015, pp. 89-116) pointed to the fact that corruption causes disruptions in the activities of governmental institutions, which is a serious obstacle in investment and innovative activities and hinders the development of entrepreneurship in terms of broader social groups (de Vaal, Ebben, 2011, pp. 108-123; Pellegrini, Gerlagh, 2004 , p. 430). Corruption in judicature can cause mistrust in the agreements made and thus radically increase the risks related to business activities. One should also bear in mind that eventually opinions regarding corruption in a given country will likely spread outside its borders leading to a gradual decline in popularity of this country among non-speculative international investors (De La Croix, Elavallade, 2011, pp. 155-187; Du, 2008, pp. 183208). This, in turn, leads to decrease in the flow of new technologies, and, as a result, hinders economic growth (Blackburn, 2012, pp. 401-402; Chang, Lu, Tsai, 2015, p. 329-330). 


\section{Literature Review}

Does corruption influence the innovative activity and economic growth in countries? The answer to this question is a resounding YES. However, one encounters conflicting opinions in the research literature when it comes to the direction of its influence, namely whether it is positive or negative. The debate on this issue started in the 1970s and continues today (Donadelli, Fasan, Magnanelli, 2014, pp. 259-272; Shaw, Katsaiti, Jurgilas, 2011, pp. 264-275; Méon, Sekkat, 2005, pp. 69-97; Dzhumashev, 2016, pp. 1169-1201).

Initially, corruption was viewed as describing all the transfers that do not influence the national income (Rose-Ackerman, 1975, pp. 187-203). This is related to the fact that in order to bribe, one first has to be in possession of money that were earned in an earlier exchange for products or services and thus have already been added to the national income. This view was contested by G. Myrdar (1968), who claimed that if corruption is allowed, it will provide an incentive for officials to invent new bureaucratic obstacles in order to encourage bribing. This way, instead of contributing to economic growth, corruption hinders it (Rose-Ackerman, 1978). Within such an approach, corruption is compared to putting sand in the wheels of the machine, in this case the economy, which can lead to a grinding halt. P. Mauro (1995, pp. 681712) spoke in a similar vein when he argued that corruption decreases the level of private investment and thus limits the economic growth. Similar research results were obtained by Brunetti and Weder (1998, pp. 513-533), as well as Mo (2001, pp. 66-79) and Luhman (1988).

A different approach to the problem of influence of corruption on economic growth was championed by Leff (1964, pp. 8-14), Huntington (1968), Leys (1965, pp. 215-230) and Bardhan (1997, pp. 1320-1346). According to this approach, given the hindering effects of the red tape on economic activity, corruption can be a factor that aids in the realisation of new economic projects. Moreover, in each case corruption can be said to contribute to an increase in the effectiveness of the work performed by the corrupted agents (Beck, Maher, 1986, pp. 337-341). All this is beneficial in terms of economic growth (Dai, Sidiropoulos, Spyromitros, 2015, pp. 523-545). For that reason, this approach compares corruption to grease put in the wheels of the machine of the economy enabling it to function more smoothly. In the context of the above approach, a common phrase used in the context of corruption: "to grease someone's palm" also comes to mind.

The research described above deals with administrative corruption, also called petty corruption. This type of corruption is related to the ways, in which the existing laws and regulations are used by officials. A separate issue dealt with in the literature is the socalled state capture. This problem was often analysed in the countries undergoing system transformation (Frye, 2002, pp. 1017-1034; Jesen, 2002, pp. 973-977; Iwasaki, Suzuki, 2007, pp. 393-422). State capture consists in an attempt at changing the institutionalised laws and regulations by individuals or groups in order to gain benefits. This means that the regulations, which by assumption should be aimed at maximising the well-being of the society are used to maximise the well-being of only a small group of individuals (Loung, Weinhal, 2004, pp. 139-152; Hellman, Geraint, Kaufmann, 2003, pp. 751-773). Such a situation results in a greater stratification of the society as a small group is gaining benefits at the cost of the other members of the society (Stigler, 1971, pp. 3-21). This approach was taken over 
and developed by the economists from the Chicago School, who pointed out that it is not only companies that are involved in regulatory capture but also various governing bodies, financial institutions, trade unions or even consumers (Backer, 1983, pp. 371-400).

The work by Habiyaremye and Raymond (2013, pp. 24-30) deserves particular attention. The authors distinguish between transnational and national corruption. The research results unambiguously show that corruptive activity on the side of transnational companies has a negative impact on all the analysed aspects of innovation. In contrast, corruptive activity on the side of national companies cannot be evaluated in such an unambiguous way.

It is worth noting that, as a result of the moral correctness related to social responsibility of business, the positive sides of corruption are often overlooked. In this context, referring to the two conflicting theories present in the literature, namely the sand-the-wheels and grease-the-wheels theories, the main research hypothesis is formulated as follows: Corruption has a positive impact on innovative activity in companies and thus on economic growth of the countries that can be described as innovation followers, moderate innovators and modest innovators.

\section{Methodology}

The conducted analysis is of static character and relates to the 2012-2013 period, which is consistent with the methodological standards described in the Oslo Manual (2005). In order to confirm or reject the research hypotheses, independent variables were defined as the fact of bribing the civil servants for help in the following: a) obtaining a construction site permit, b) positive tax vetting of a company by tax-office inspectors, c) obtaining an import licence (a permission for bringing goods in, if a given country requires it), d) obtaining a business licence, in cases where required.

The above-mentioned variables reflect the questions found in the questionnaire designed for the European Bank for Reconstruction and Development (EBRD) and the World Bank (WB). Questions were multiple-choice with respondents having to select one option from the following list: a) yes, a bribe was given; b) no, a bribe was not given; c) I do not know; d) refusal to answer. The structure of the answers for different countries was divided into positive answers (indicating whether a bride was or was not given) and negative answers (not knowing whether a bribe was given or refusal to answer), this data is presented in Appendix 1. The analysis takes into account only those companies that provided a positive (1) or negative answer (0) meaning that the independent variable was binary.

The dependent variables characterised the innovative activity of companies as divided into hard and soft innovations. Hard innovations consisted of the following: a) product innovations (introducing new product into the market), b) process innovations (making improvements in the production methods), c) research and development (R\&D) activity, d) investments. Soft innovations consisted the following: a) marketing innovations, b) organisational innovations, c) quality certifications, d) support and logistics systems. In the case of the dependent variables, the respondent also had to choose one out of the possible answers: a) yes, a specific aspect of innovative activity was introduced, b) no, this aspect of innovative activity was not introduced, c) I do not know. Among the dependent 
variables, the only entities selected for further analysis were those that provided a positive (yes, a given aspect of innovative activity was introduced in the company) or negative (no, a given aspect of innovative activity was not introduced in the company) answers, hence the dependent variable also became binary.

The fact that the dependent variable is binary means that the method of multiple regression has a limited applicability. One can, however, make use of logistic or probit modelling. In this article the method of probit modelling was chosen, as it allows one to obtain probability values for the occurrence of a given attribute of innovative activity. These values provide information whether the probability of occurrence of a given attribute is low (less than 10\%) or very high (e.g. 70-80\%). The method of logistic modelling does not provide one with such a point of reference. One obtains odds ratio providing information with regard to odds of a given innovative activity attribute occurring given a specific independent variable.

As probit modelling has been described in many publications (Maddala, 1983; Habiyaremye, Raymond, 2013, pp. 18-19; Tomaszewski, 2015, p. 209), it is not a subject of detailed review in this article. It is worth noting, however, that the obtained probit models, in the context of the problems tackled here, determine the probability of a given attribute of innovative activity when corruption does or does not occur. The sign of a parameter in the probit model determines the direction of impact of the independent variable on the probability of a given event occurring. The plus sign means that the probability that the dependent variable is 1 increases, whereas the minus sing means that this probability decreases. Interpreting the above in the context of analysing innovative activity, it can be said that if the model has the plus sign, the probability of a given attribute of innovative activity occurring in the analysed group of companies (e.g. those where corruption occurs) is higher than in the opposite group (in this case, the companies where corruption does not occur).

This analysis is based on calculations performed using the Statistica suite. The models were calculated separately for companies grouped in three sections: a) taking into account the size, the companies were divided into micro, small, medium and large b) taking into account the legal ownership, the companies were divided into domestic-, foreign- and mixedownership, c) taking into account the scope of sales, the companies were divided into local-, domestic- and international-market. For the companies in the first section, 128 models were obtained, for the companies grouped in the remaining two sections, 96 models each were obtained. In total, 320 models were obtained, with only the 29 statistically-significant ones presented and analysed in the remainder of this article.

\section{Description of the Sample}

The empirical data, on the basis of which the calculations have been made and the subsequent results interpreted, were obtained during the 5 th round of research on business environment conducted in the period between 2012-2013 for the EBRD and WB. During the analysis, empirical data was obtained from 15,883 companies from 30 different countries in Central and Eastern Europe and Asia. With the exception of Turkey, all the analysed countries were at some point socialist, centrally-planned, economies. Taking into account their level 
of innovative activity, these countries can be classified as: innovation followers, moderate innovators and modest innovators.

The entities to be analysed were chosen using the method of stratified random sampling, with strata being defined in relation to region, sector and the size of the company (http://www.enterprisesurveys.org/Methodology/). The selected companies engaged in retail, services and production activities. All of them hired at least 5 employees full-time. All types of government-related institutions were excluded, e.g. army, police, health services and education. The analysed companies belong to the following categories of ISIC Rev 3.1:

- D - manufacturing,

- $\mathrm{F}$ - construction,

- $\mathrm{G}$ and $\mathrm{H}$ - services,

- I - transport, storage and communications.

The analysis did not take into account the companies classified as $\mathrm{J}$ and $\mathrm{K}$ (financial and insurance activities and real estate activities) apart from subsection 72 that deals with computer and related activities. Moreover, the analysis did not take into account agriculture and mining companies.

The companies that in the year before the analysis had contact with public administration units, either out of their own will or otherwise, were also singled out from the sample. If the contact was initiated by the companies, it was related to the following: a) obtaining a construction permit, b) obtaining an import licence, c) obtaining a business licence. If the contact was initiated by public administration units, it was related to an inspection conducted by the tax-office inspectors. The number of entities that had contact with public administration units for the above-mentioned reasons is presented in the following Table 1.

Table 1 | Number of Companies that Had Contact with Public Administration Units in the Period 2012-2013

\begin{tabular}{|c|c|c|}
\hline Number & Detailed Description & Number \\
\hline \multirow[t]{4}{*}{1} & Companies seeking the construction permit & \\
\hline & Number of companies that decided to bribe officials in order to secure permit & 325 \\
\hline & Number of companies seeking the permit & 2,181 \\
\hline & Structure (in \%) & 14.9 \\
\hline \multirow[t]{4}{*}{2} & Companies under control by tax-office inspectors in the previous tax year & \\
\hline & Number of companies that decided to bribe the tax-office inspectors & 934 \\
\hline & Number of companies subjected to inspection by tax-office inspectors & 8,739 \\
\hline & Structure (in \%) & 10.7 \\
\hline \multirow[t]{4}{*}{3} & Companies seeking import licence & \\
\hline & Number of companies that decided to bribe officials in order to secure licence & 75 \\
\hline & Number of companies seeking the licence & 997 \\
\hline & Structure (in \%) & 7.5 \\
\hline \multirow[t]{4}{*}{4} & Companies seeking the business licence & \\
\hline & Number of companies that decided to bribe officials in order to secure licence & 274 \\
\hline & Number of companies seeking the licence & 2,860 \\
\hline & Structure (in \%) & 9.6 \\
\hline
\end{tabular}

Source: Own analysis on the basis of BEEPS 2013 


\section{Corruption and Hard Innovative Activity of Companies}

Twelve statistically significant models were obtained as a result of the analysis of the relationship between corruption and hard innovative activity, which are presented in Appendix 2. The models show that corruption negatively influences both the investment aspect of innovative activity and R\&D activity, which is consistent with the sand-the-wheels theory. The probability of investment in a company where corrupting activities were present, corrupting companies, decreased by $15 \%$ to almost $73 \%$ than in those where corruption was absent, non-corrupting companies. This tendency was observed in the group of: a) microcompanies operating on a national market, b) micro-companies with mixed ownership, c) companies operating on an international market.

In the case of $\mathrm{R} \& \mathrm{D}$, the probability of this activity in corrupting companies was in extreme cases even sevenfold lower than in the non-corrupted companies. This tendency was observed in the group of: a) small national companies operating on a trans-regional market, b) companies with national ownership, c) companies operating on a local market.

The causes of a negative dependence between corruption and investment in R\&D for micro- and small companies can be related to the limited capital and personal resources at the disposal of such companies. The management in such companies, given unfavourable political and legal conditions, instead of focussing on innovatively based activities have to solve problems regarding the company's relations with public administration. This takes time and money, which in other conditions could be used to fund innovation. Moreover, corrupting the public administration officials can be an alternative to innovative activity in terms of becoming successful in the market. Instead of investing in new or improved products, the companies can, for instance, lobby in a more or less official way for limiting the number of entities that are permitted to offer a given product. A smaller number of licensed importers means that the market is less competitive, and hence the profit margins are higher translating to a higher profit for such companies compared to the situation when market competitiveness is not restrained.

Moreover, the existence of corruption means that the system, in which companies function, is more unpredictable. This also discourages investments, in terms of money and time, in the company, as the changes in public administration, on which the micro- and small companies have no influence, can cause a given company to loose e.g. import licence that is a crucial component of its being active on the market.

Different results were obtained in terms of the probit models describing the relation between corruption and product innovations. In this case, this relation is positive confirming the grease-the-wheels theory. In the corrupting companies, the probability of product innovation increase by $17 \%$ to $19 \%$ than in the companies that did not corrupt the public administration officials. This tendency was noticeable in the national-level companies and those with trans-regional scope of sales. In that respect, the obtained results are consistent with the conclusions of Habiyaremye and Raymond research (2013).

The requirement of business licences is indicative of state interventionist policies present in a given market. It is also an obstacle for economic activity related to administrative 
and legal environments. In such circumstances, the more pragmatic entrepreneurs attempt to gain an upper hand over the competitors by means of corrupting the public administration officials responsible for issuing the licence. Bribing an official means that the company starts its activity quicker, gaining an edge over the competition (Thede, Gustafson, 2012, pp. 651-666). And since the start of the licensed activity means introducing a new product on the market (new at least company-wise), the relation between licence bribes and product innovations is positive.

Other causes underlie the positive relation between corrupting the tax-office inspectors and product innovations. By corrupting the inspectors, the company ensures positive and friendly relations with the institutions the inspectors represent. Entrepreneurs, instead of wasting time and money on proving their honesty can focus on their development, which translates into broadening the product range or entering new markets. Moreover, corrupting relevant officials can help, in the view of entrepreneurs, ensure a safer and more stable environment, thus aid further product development.

\section{Corruption and Soft Innovative Activity of Companies}

Seventeen probit models were obtained as a result of the analysis of the relation between corruption and soft innovative activity, which are presented in Appendix 3. Analysing these models one immediately notices that there are more positive than negative models confirming the grease-the-wheels theory. Only in the case of quality certifications one encounters a strong negative relation confirming the sand-the-wheels theory. In case of support and logistics system, the probability of these systems being implemented in the corrupting companies, was, depending on the size of the company ranged from $42 \%$ to $53 \%$ higher than in the case of companies that did not corrupt the public administration officials. In the case of marketing and organisational innovations, the probability of these aspects of innovative activity in the corrupting companies was $32 \%$ and $46 \%$ higher, respectively. A different trend was observed in the case of quality certifications. The probability of this aspect of innovative activity in the corrupting companies ranged from $43 \%$ to $50 \%$ lower than in the case of the non-corrupting ones. In case of support and logistics systems and, indirectly, in the case of quality certification, the change in company's size did not influence how corruption related to this innovative activity, i.e. these tendencies were preserved in the companies belonging to different size classes. In case of support and logistics systems it was also observed that the increase in company's size resulted in an increase in the probability of these systems being implemented from $17 \%$ to $23 \%$.

The models and probability values obtained for the companies of medium size allowed a conclusion that in the corrupting companies, the probability of implementing quality certification was higher than the probability of implementing support and logistics systems. An analogous pattern was observed in the case of the non-corrupting companies.

The negative relationship between corruption and implementation of quality certification is widely discussed in the subject literature (Ullah, Wei, 2013; Paunov, 2016, pp. 216-231). It is worth pointing out, however, that when the competition is strong, 
the importance of quality certification decreases, as it is commonly assumed that such certification was obtained via dishonest methods (Montiel, Husted, Christmann, 2012, pp. 1103-1113). Moreover, entrepreneurs who try to obtain quality certification are interested in building a positive and credible image of both the product and the company, and that is perceived to stand in opposition to what corruption represents (Beck, Demirguc-Kunt, Maksimovic, 2005, pp. 137-177).

A positive relationship between corruption, marketing and organisational innovations as well as the support and logistics systems deserves a closer attention.

Positive relationship between corruption and marketing innovations occurred in small companies, of mixed or international ownership, which operated on national markets. In the obtained models, there was only one dependent variable: bribes for the tax-office inspectors. This means that marketing innovations are closely related to the fiscal activities within companies. One should also keep in mind that the companies are obliged to produce financial reports controlled by independent auditors and tax-office inspectors. For this reason the funds spent on corruption have to be covered up by more or less fictional financial operations, which are at the same time probable enough so as not to raise suspicion in the inspecting entities. Marketing is one of the areas that suits perfectly that kind of purposes. Spending related to creating an image or brand is so diverse and non-typical that it can easily hide the additional spending related to corruption. Under the guise of organising a business meeting with a contractor or a raffle for the customers one can easily fund an expensive dinner or even exotic holidays for the public administration official responsible for making decisions that influence the fate of an undertaking or project the company is interested in. The workshops and conferences organised by pharmaceutical companies for the health services employees that often take place in luxurious and exotic locations are a perfect example of such practices ${ }^{1}$. In return for, in effect, attractive holidays, a pharmaceutical company expects the participants to prescribe their patients the medications produced by this company (Vian, Brinkerhoff, Feeley, Salomon, Vien, 2012, pp. 49-63; Gaitonde, Oxman, Okebukola, Rada, 2016). The marketing department is also responsible for creating marketing gadgets, which can include expensive liquors, leather clothing, jewellery and the most up-to-date electronic equipment. Moreover, informal relations with marketing agencies or consulting firms allow the company to hide spending related to bribes. In such a case, the task of the marketing department is to make the cover-up activities seem more believable, which often takes the shape of claiming marketing innovations. It should be noted, however, that not every instance of marketing action should be considered as related to corruption as this would be a gross and harmful simplification. Marketing innovations span a wide range of activities realised both by the companies that corrupt the public administration officials and those that do not. In absolute terms, only a small number of marketing innovations serve as a cover-up for corruptive activities.

The factor that increases the chances of corrupting public administration officials is related to entering the indirect contact (direct contacts are more easily discovered and hence tend to be avoided by the interested parties) with them on a professional

1 cf. media reports about the company GlaxoSmithKline from 2016 year. 
or private level. To this end, entrepreneurs can hire politicians or former managementlevel officials, who are familiar with the procedures and those in power in various public offices. Such individuals are hired on positions created especially for them that come with a sufficiently-high salary and a small scope of responsibilities so that the everyday business of the company is not affected. One should keep in mind that a politician (who is often educated in political or historical sciences) or a former official often does not have sufficient professional qualifications to be hired in a given company and the only reason for this to happen is his or her connections within the public administration. Creating a new job position means a change in company's organisational structure, hence this actions is a form of organisational innovation. In describing the organisational schema of a company one has to come up with a convincing justification for the creation of the job position and its impact on the functioning of the company. Such conceived 'organisational innovation' can result in increased orders from public administration or in higher prices the administration unit pays for the offered products or services. This means that on the micro scale, the impact of corruption is consistent with the grease-the-wheels theory in terms of company's development, yet on the macro scale the benefits related to higher profits of this entity would cancel out with the losses described in the sand-the-wheels theory for the entire economy.

The final aspect of innovative activity, where a positive impact of corruption is noted is the support and logistics systems. Describing the relation between corruption and the support and logistics systems it should be observed that it is increasingly the case in modern companies that the ownership is separated from the management. In other words, someone else is the owner and someone else manages the company. Thus, one observes a temptation of those managing the company to obtain additional benefits in relation to their work. The smaller their salary is, as conceived by them, the stronger the temptation. And since the management does not feel like the owners of the company, there is less resistance to abuse their position in order to achieve private benefits.

Implementing support and logistics system in a company can serve as an opportunity to do so. Such systems are very expensive and there is a lot of variation among them. Moreover, the knowledge of the agencies supervising the companies with relation to the range of these systems and their characteristics is limited. Adding to this strong competitiveness levels among the companies providing such systems, one obtains an easy explanation of the positive relation between corruption and implementing support and logistics systems.

The resistance of the employees responsible for the logistic aspects of managing a company can be lessened by corruption related to such activity, which is confirmed by press reports $^{2}$.

2 Information on corruption in international supermarket chains, Polish Armament Holding and among the custom officers in relation to a tobacco affair that spread all over EU can serve as examples of such reports in Poland in the period 2015/2016. In all the above, an important role was played by those responsible for supply and logistics in both state-owned and private companies. 


\section{Conclusions}

Concluding the analysis of the obtained probit models, one can say that they confirm both theories explaining the impact of corruption on innovation and economic growth. In terms of hard innovative activity, corruption had a negative impact on the financial aspects of investment and R\&D. Whereas in terms of soft innovative activity, it impacts the implementation of quality certification. Corruption, however, was shown to have a positive effect on the implementation aspects in terms of introducing new products. In terms of soft innovative activity, corruption had a positive impact on the implementation of marketing and organisational innovations and of support and logistics systems. It is worth noting that no statistically-significant models were obtained for the impact of corruption on process innovations.

From the point of view of hard innovations, one can say that the negative impact of corruption is visible mainly in relation to investment. Yet, the most serious consequences for economic growth are related to the negative impact of corruption on $\mathrm{R} \& \mathrm{D}$, especially in the following countries: Slovenia, the Czech Republic, Hungary and Estonia ${ }^{3}$. In these countries, similarly to Poland, Slovakia, Lithuania, Latvia and Croatia the use of low salary levels as competitive edge is slowly becoming impractical. An increase in salary levels means that the prices of goods produced in these countries will be comparable with the prices of goods produced by highly-developed countries, decreasing their competitiveness. For this reason, the only chance for the companies from the moderate-innovators and catching-up countries is to engage in innovative activity and R\&D and to search market niches unnoticed by the companies from the countries that are innovation leaders and innovation followers.

Analysing the positive influence of corruption on the chosen aspect of soft innovative activity one should point out that this positive influence is only noticeable on the microeconomic scale. It does not appear on the macro-economic scale, since the discussed expressions of innovative activity result in an income increase in companies at the expense of other entities or social groups. At the same time, one notices a decrease in trust in state institutions and an increase in transaction costs and risk in terms of engaging in business activity.

The positive impact of corruption on product innovations, categorised as hard innovation, has to be explained in a different way. This relation should be interpreted by taking into account the country, from which these companies come from. In this case, these are the former socialist countries with complex and burdensome public administration. In such conditions corruption can potentially speed up the implementation of new product innovations, which also has a stimulating impact on economy at large.

On the basis of the above analysis one can also say that the research hypothesis has been only partially confirmed. This means that the sand-the-wheels and grease-the-wheels theories are not mutually exclusive but complementary. Depending on circumstances,

3 In these countries, the GERD indicator was as follows: Slovenia - 2.59\%, the Czech Republic 1.91\%, Estonia $-1.74 \%$, Hungary $1.41 \%$. In all the other analysed countries this indicator was between 0.12 and $1.1 \%$. 
one can find arguments for the positive impact of corruption on innovative activity and economic growth, confirming the views presented by Leff, Huntington and Leys. It can be said that this article also confirms the validity of the grease-the-wheels theory when compared with the strict understanding of the sand-the-wheels theory. However, extensive research is required to identify the precise conditions when corruption has a positive impact on innovative activity and economic growth.

Let us end the analysis of the impact of corruption on innovative activity and economic growth with quoting the mercantilist rule saying that a private disadvantage, and corruption can no doubt be described as such, can be turned into a social benefit. As a result of corruption, other entrepreneurs can gain additional, legal profits. For example, the restaurant owners make profit on preparing expensive fancy dinners for the corrupted officials, the hotel owners make profit on organising conferences or workshops, the liquor vendors make profit on selling the most expensive alcohols and other manufacturers make profit on reshaping standard products into expensive marketing gadgets. Moreover, the corrupted officials earn more and consequently can spend more on their needs with all this money sooner or later finding its way to honest entrepreneurs. 
Appendix 1 | The Rate of Corrupting Companies in Relation to a Total Number of Companies that Applied for a Permit, Licence or Were Inspected by Tax-Office Inspectors

\begin{tabular}{|c|c|c|c|c|c|c|c|c|c|}
\hline \multirow{3}{*}{ Number } & \multirow{3}{*}{ Country } & \multicolumn{8}{|c|}{$\begin{array}{l}\text { Structure of companies that bribed public administration officials in } \\
\text { relation with: }\end{array}$} \\
\hline & & \multicolumn{2}{|c|}{$\begin{array}{c}\text { obtaining } \\
\text { construction } \\
\text { permit }\end{array}$} & \multicolumn{2}{|c|}{$\begin{array}{l}\text { inspection } \\
\text { of a tax-office } \\
\text { inspectors }\end{array}$} & \multicolumn{2}{|c|}{$\begin{array}{l}\text { obtaining } \\
\text { import licence }\end{array}$} & \multicolumn{2}{|c|}{$\begin{array}{c}\text { obtaining } \\
\text { business } \\
\text { licence }\end{array}$} \\
\hline & & CB & CRA & CB & CRA & CB & CRA & CB & CRA \\
\hline 1 & Albania & 15.38 & 23.08 & 17.43 & 3.36 & 0 & 14.28 & 9.52 & 9.52 \\
\hline 2 & Armenia & 24.24 & 6.06 & 7.25 & 0.36 & 3.13 & 0 & 7.41 & 1.85 \\
\hline 3 & Azerbaijan & 10.00 & 20.00 & 14.83 & 1.58 & 0 & 31.58 & 0 & 33.33 \\
\hline 4 & Belarus & 4.35 & 5.80 & 3.47 & 1.39 & 0 & 7.14 & 1.33 & 6.67 \\
\hline 5 & $\begin{array}{l}\text { Bosnia and } \\
\text { Herzegovina }\end{array}$ & 9.33 & 4.00 & 9.59 & 2.58 & 3.77 & 3.77 & 8.11 & 8.11 \\
\hline 6 & Bulgaria & 11.43 & 5.71 & 4.37 & 1.64 & 0 & 0 & 10.64 & 2.13 \\
\hline 7 & Croatia & 5.45 & 5.45 & 0 & 0 & 5.36 & 1.79 & 6.06 & 4.55 \\
\hline 8 & Czech Republic & 4.48 & 2.99 & 6.98 & 0 & 9.09 & 18.18 & 3.45 & 0 \\
\hline 9 & Estonia & 0 & 0 & 0 & 4.69 & 0 & 0 & 0 & 5.26 \\
\hline 10 & Georgia & 8.11 & 0 & 1.08 & 1.08 & 0 & 0 & 0 & 0 \\
\hline 11 & Hungary & 0 & 9.38 & 0 & 1.28 & 0 & 0 & 4.0 & 16.0 \\
\hline 12 & Kazakhstan & 22.35 & 9.41 & 18.42 & 5.26 & 18.18 & 18.18 & 11.81 & 40.74 \\
\hline 13 & Kosovo & 15.69 & 0 & 2.70 & 0 & 0 & 0 & 1.96 & 1.96 \\
\hline 14 & Kyrgyzstan & 36.67 & 1.67 & 46.75 & 2.85 & 54.17 & 0 & 43.42 & 6.58 \\
\hline 15 & Latvia & 2.86 & 8.57 & 1.57 & 3.94 & 0 & 0 & 0 & 6.45 \\
\hline 16 & Lithuania & 16.13 & 12.90 & 7.5 & 2.5 & 6.67 & 0 & 2.0 & 8.0 \\
\hline 17 & Macedonia & 11.11 & 4.76 & 3.68 & 0.37 & 2.17 & 2.17 & 3.03 & 3.03 \\
\hline 18 & Moldova & 18.69 & 26.17 & 15.13 & 8.86 & 24.32 & 5.41 & 7.78 & 5.56 \\
\hline 19 & Mongolia & 36.67 & 2.22 & 13.10 & 1.59 & 14.15 & 1.85 & 26.32 & 2.63 \\
\hline 20 & Montenegro & 15.00 & 25.00 & 10.53 & 8.77 & 2.7 & 16.22 & 0 & 8.33 \\
\hline 21 & Poland & 1.69 & 3.39 & 1.41 & 1.41 & 0 & 6.25 & 0 & 14.29 \\
\hline 22 & Romania & 9.62 & 5.77 & 7.33 & 2.05 & 0 & 0 & 7.03 & 0.78 \\
\hline 23 & Russia & 19.66 & 16.70 & 6.29 & 3.98 & 6.58 & 19.74 & 8.18 & 8.49 \\
\hline 24 & Serbia & 10.17 & 6.78 & 5.63 & 4.23 & 5.71 & 0 & 5.26 & 10.53 \\
\hline 25 & Slovakia & 6.06 & 0 & 2.52 & 0.79 & 20.0 & 0 & 4.55 & 0 \\
\hline 26 & Slovenia & 1.82 & 3.64 & 1.96 & 0 & 0 & 0 & 0 & 2.56 \\
\hline 27 & Tajikistan & 13.04 & 18.84 & 29.32 & 2.81 & 10.0 & 6.67 & 17.65 & 10.92 \\
\hline 28 & Turkey & 7.05 & 3.85 & 3.04 & 0.53 & 3.14 & 3.67 & 14.81 & 3.87 \\
\hline 29 & Ukraine & 44.19 & 25.58 & 35.43 & 8.82 & 21.21 & 33.33 & 17.55 & 21.81 \\
\hline 30 & Uzbekistan & 2.99 & 2.99 & 5.70 & 0 & 0 & 0 & 6.41 & 2.56 \\
\hline \multicolumn{2}{|l|}{ Average } & 12.81 & 8.69 & 9.43 & 2.56 & 7.01 & 6.34 & 7.61 & 8.22 \\
\hline
\end{tabular}

Notes: $\mathrm{CB}$ - the companies that bribed; CRA - the companies that refused to answer.

Source: Own analysis on the basis of BEEPS 2013 
Appendix 2 | Probit Models Depicting the Impact of Corruption on Hard Innovative Activity Divided into Classes of Size, Type of Ownership and Sales Range

\begin{tabular}{|c|c|c|c|c|c|c|c|c|c|c|c|}
\hline \multirow[b]{2}{*}{ Number } & \multirow{2}{*}{$\begin{array}{l}\text { Criteria } \\
\text { division } \\
\text { of the } \\
\text { companies }\end{array}$} & \multirow[b]{2}{*}{ Bribes } & \multicolumn{3}{|c|}{ Product innovations } & \multicolumn{3}{|c|}{ Investments } & \multicolumn{3}{|c|}{$R \& D$} \\
\hline & & & $S E$ & $\mathbf{P}_{1}$ & $\mathbf{P}_{2}$ & SE & $\mathbf{P}_{1}$ & $\mathbf{P}_{2}$ & $S E$ & $\mathbf{P}_{1}$ & $\mathbf{P}_{2}$ \\
\hline \multirow{8}{*}{1} & \multirow{8}{*}{$\begin{array}{l}\text { Classes } \\
\text { of size }\end{array}$} & \multicolumn{10}{|c|}{ Micro companies } \\
\hline & & \multirow{2}{*}{$\begin{array}{l}\text { Bribes for } \\
\text { construction permit }\end{array}$} & & & & \multicolumn{3}{|c|}{$-0.25 x+0.49$} & & & \\
\hline & & & & & & 0.11 & 0.60 & 0.69 & & & \\
\hline & & \multirow{2}{*}{$\begin{array}{l}\text { Bribes for import } \\
\text { licence }\end{array}$} & & & & \multicolumn{3}{|c|}{$-0.52 x+0.28$} & & & \\
\hline & & & & & & 0.23 & 0.41 & 0.61 & & & \\
\hline & & \multicolumn{10}{|c|}{ Small companies } \\
\hline & & \multirow{2}{*}{$\begin{array}{l}\text { Bribes for import } \\
\text { licence }\end{array}$} & & & & & & & & $1 x-0$. & \\
\hline & & & & & & & & & 0.45 & 0.03 & 0.20 \\
\hline \multirow{10}{*}{2} & \multirow{10}{*}{$\begin{array}{l}\text { Type of } \\
\text { ownership }\end{array}$} & \multicolumn{10}{|c|}{ Domestic-ownership companies } \\
\hline & & \multirow{2}{*}{$\begin{array}{l}\text { Bribes for the tax- } \\
\text {-office inspectors }\end{array}$} & & & & & & & \multicolumn{3}{|c|}{$-0.12 x-1.22$} \\
\hline & & & & & & & & & 0.06 & 0.09 & 0.11 \\
\hline & & \multirow{2}{*}{$\begin{array}{l}\text { Bribes for import } \\
\text { licence }\end{array}$} & & & & & & & \multicolumn{3}{|c|}{$-0.60 x-0.86$} \\
\hline & & & & & & & & & 0.26 & 0.07 & 0.20 \\
\hline & & \multirow{2}{*}{$\begin{array}{l}\text { Bribes for business } \\
\text { licence }\end{array}$} & \multicolumn{3}{|c|}{$+0.17 x-0.55$} & & & & & & \\
\hline & & & 0.09 & 0.35 & 0.29 & & & & & & \\
\hline & & \multicolumn{10}{|c|}{ Mixed-ownership companies } \\
\hline & & \multirow{2}{*}{$\begin{array}{l}\text { Bribes for import } \\
\text { licence }\end{array}$} & & & & \multicolumn{3}{|c|}{$-0.76 x+0.50$} & & & \\
\hline & & & & & & 0.36 & 0.40 & 0.69 & & & \\
\hline & & & & & -ocal r & arket & & & & & \\
\hline & & Bribes for & & & & & & & & $8 x+1$ & \\
\hline & & construction permit & & & & & & & 0.13 & 0.12 & 0.19 \\
\hline & & & & & mesti & mark & & & & & \\
\hline & & Bribes for & & & & & $6 x+0$ & & & & \\
\hline & & construction permit & & & & 0.12 & 0.65 & 0.77 & & & \\
\hline 3 & Sales range & Bribes for the tax- & +0 & $6 x-0$ & & & & & & & \\
\hline & & -office inspectors & 0.07 & 0.37 & 0.31 & & & & & & \\
\hline & & Bribes for import & & & & & & & -0 & $6 x-0$ & \\
\hline & & licence & & & & & & & 0.30 & 0.08 & 0.23 \\
\hline & & & & Int & natio & al mar & & & & & \\
\hline & & Bribes for the tax- & & & & -0 & $2 x+0$ & & & & \\
\hline & & office inspectors & & & & 0.20 & 0.42 & 0.59 & & & \\
\hline
\end{tabular}

Notes: $\mathrm{SE}$ - standard error; $\mathrm{P}_{1}$ - the probability of a given event occurring in a given group of companies; $\mathrm{P}_{2}$ - the probability of a given event occurring in the remaining groups of companies.

Source: Own analysis on the basis of BEEPS 2013 
Appendix 3 | Probit Models Depicting the Impact of Corruption on Soft Innovative Activity Divided into Classes of Size, Type of Ownership and Sales Range

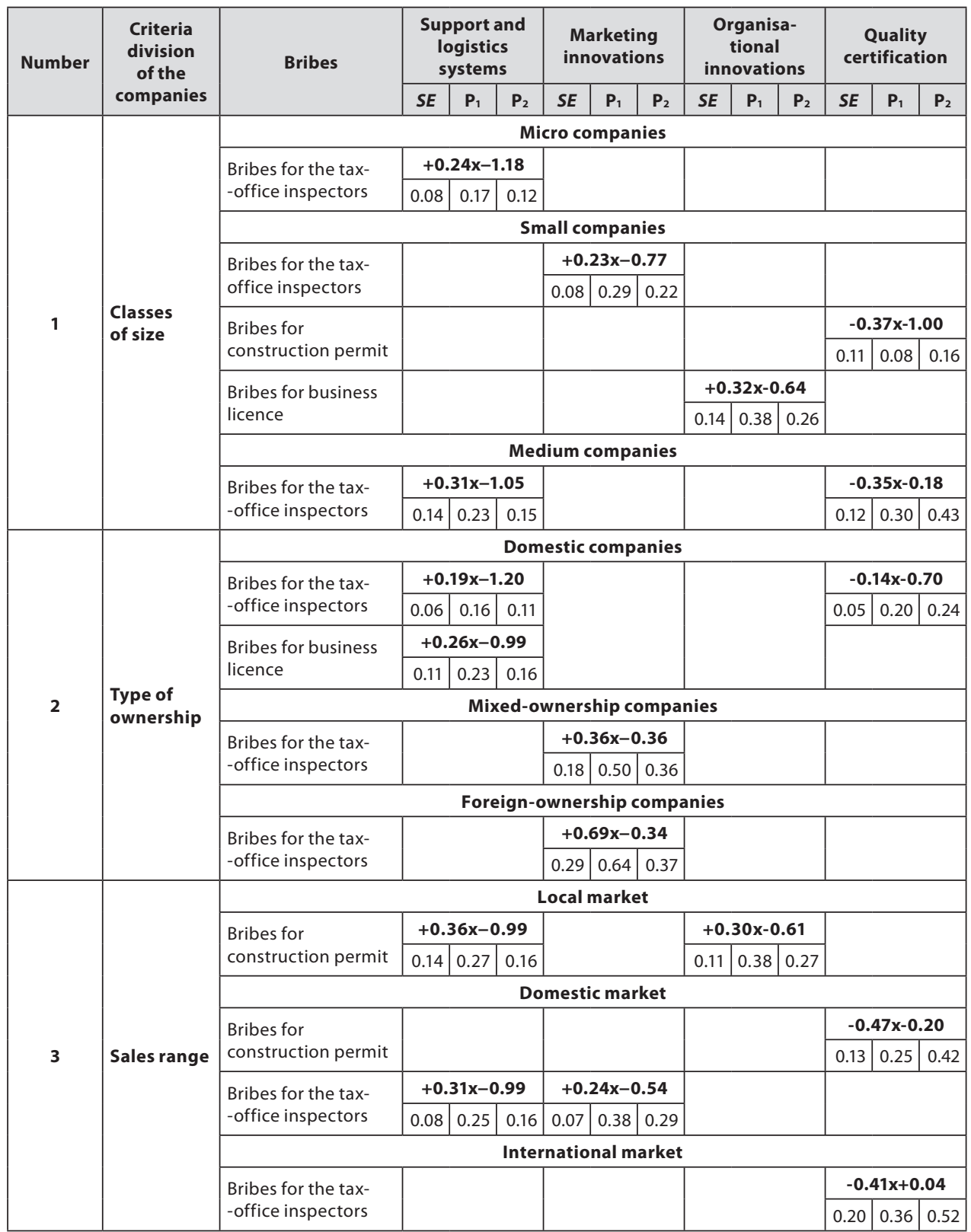

Source: Own analysis on the basis of BEEPS 2013 


\section{References}

Backer, G. S. (1983). The Theory of Competition among Pressure Groups Form Political Influence. Quarterly Journal of Economics, 98(3), 371-400, http://doi.org/10.2307/1886017

Bardhan, P. (1997). Corruption and Development: A Review of Issues. Journal of Economic Literature, 35(3), 1320-1346

Beck, P. J., Maher, M. W. (1986). A Comparison of Bribery and Bidding in Thin Markets. Economics Letters, 20(1), 1-5, http://doi.org/10.1016/0165-1765(86)90068-6

Beck, T., Demirguc-Kunt, A., Maksimovic, V. (2005). Financial and Legal Constraints to Firm Growth: Does Firm Size Matter? Journal of Finance, 60(1), 137-177, http://doi.org/10.1111/j.1540-6261.2005.00727.x

Blackburn, K. (2012). Corruption and Development: Explaining the Evidence. The Manchester School, 80(4), 401-428, http://doi.org/10.1111/j.1467-9957.2012.02314.x

Blackburn, K., Powell, J. (2011). Corruption, Inflation and Growth. Economics Letters, 113(3), 225-227, https://doi.org/10.1016/j.econlet.2011.06.015

Börzel, T. A, van Hüllen, V. (2014). State-Building and the European Union's Fight against Corruption in the Southern Caucasus: Why Legitimacy Matters. Governance:

An International Journal of Policy, Administration, and Institutions, 27(4), 613-634, http://doi.org/10.1111/gove.12068

Brunetti, A., Weder, B. (1998). Investment and Institutional Uncertainty: A Comparative Study of Different Uncertainty Measures. Weltwirtschaftliches Archiv, 134(3), 513-533, http://doi.org/10.1007/bf02707928

Chang, J.-J., Lu, H-Ch., Tsai, H-F (2015). Corruption, Growth, and Increasing Returns to Production Specialization. International Journal of Economic Theory, 11(3), 329-345, http://doi.org/10.1111/ijet.12067

Cosenz, F., Noto, G. (2014). Dynamic Simulation Approach to Frame Drivers and Implications of Corruption Practices on Firm Performance. European Management Review, 11(3-4), 239-257, http://doi.org/10.1111/emre.12037

Dai, M., Sidiropoulos, M., Spyromitros, E. (2015). Fiscal Policy, Institutional Quality and Central Bank Transparency. The Manchester School, 83(5), 523-545, September, http://doi.org/10.1111/manc.12067

De La Croix, D., Elavallade, C. (2011). Democracy, Rule of Law, Corruption Incentives, and Growth. Journal of Public Economic Theory Democracy, 13(2), 155-187, https://doi.org/10.1111/j.1467-9779.2011.01497.x

de Vaal, A., Ebben, W. (2011). Institutions and the Relation between Corruption and Economic Growth. Review of Development Economics, 15(1), 108-123, http://doi.org/10.1111/j.1467-9361.2010.00596.x

Donadelli, M., Fasan, M., Magnanelli, B. S. (2014). The Agency Problem, Financial Performance and Corruption: Country, Industry and Firm Level Perspectives. European Management Review, 11(3-4), 259-272, http://doi.org/10.1111/emre.12038

Du, J. (2008). Corruption and Corporate Finance Patterns: An International Perspective. Pacific Economic Review, 13(2), 183-208, http://doi.org/10.1111/j.1468-0106.2008.00396.x

Dzhumashev, R. (2016). The Role of Income Uncertainty in the Corruption-Growth Nexus. The B. E. Journal of Economic Analysis \& Policy, 16(2), http://doi.org/10.1515/bejeap-2015-0056

Frye, T. (2002). Capture or Exchange? Business Lobbying in Russia. Europe-Asia Studies, 54(7), 1017-1036, http://doi.org/10.1080/0966813022000017113 
Gaitonde, R., Oxman, A. D., Okebukola, P. O., Rada, G. (2016). Interventions to Reduce Corruption in the Health Sector. Cochrane Database of Systematic Reviews, (8), http://doi.org/10.1002/14651858.CD008856.pub2

Habiyaremye, A., Raymond, W. (2013). Transnational Corruption and Innovation in Transition Economies. UNU-MERIT. Working Paper No. 50.

Haque, M. E., Kneller, R. (2015). Why Does Public Investment Fail to Raise Economic Growth? The Role of Corruption. The Manchester School, 83(6), 623-651, http://doi.org/10.1111/manc.12068

Hellman, J. S., Geraint, J., Kaufmann, D. (2003). Seize the State, Seize the Day: State Capture and Influence in Transition Economies. Journal of Comparative Economy, 31 (4), 751-773, http://doi.org/10.1016/j.jce.2003.09.006

Huntington, S. P. (1968). Political Order in Changing Societies. New Haven, CT: Yale University Press. ISBN 9780300011715.

Ivanyna, M., Moumouras, A., Rangazas, P. (2016). The Culture of Corruption, Tax Evasion, and Economic Growth, Economic Inquiry, 54(1), 520-542, January 2016, http://doi.org/10.1111/ecin.12228

Iwasaki, I., Suzuki, T. (2007). Transition Strategy, Corporate Exploitation, and State Capture: An Empirical Analysis of Former Soviet States. Communist and Post-Communist Studies, 40(4), 393-422, http://doi.org/10.1016/j.postcomstud.2007.10.001

Jesen, N. (2002). Economic Reform, State Capture, and International Investment in Transition Economies. Journal of International Development, 14(7), 973-977, http://doi.org/10.1002/jid.937

Keig, D. L., Brouthers, L. E., Marshall, V. B. (2015). Formal and Informal Corruption Environments and Multinational Enterprise Social Irresponsibility. Journal of Management Studies, 52(1), Januar, 89-116, http://doi.org/10.1111/joms.12102

Kunieda, T., Okada, K., Shibata, A. (2016). Corruption, Financial Development and Economic Growth: Theory and Evidence from an Instrumental Variable Approach with Human Genetic Diversity. Economic Notes, 45(3), 353-392, https://doi.org/10.1111/ecno.12061

Leff, N. (1964). Economic Development through Bureaucratic Corruption. American Behavioral Scientist, 8(3), 8-14, http://doi.org/10.1177/000276426400800303

Leys, C. (1965). What Is the Problem about Corruption? Journal of Modern African Studies 3, in Heidenheimer, A. J., Johnston, M., LeVine, V. T., ed., (1989), Political Corruption:

A Handbook. Oxford: Transaction Books.

Lien D. H. D. (1986). A Note on Competitive Bribery Games. Economics Letters, 22(4), 337-341, http://doi.org/10.1016/0165-1765(86)90093-5

Loung, P. J., Weinhal, E. (2004). Contra Coercion: Russian Tax Reform, Exogenous Shock, and Negotiated Institutional Charge. The American Political Science Review, 98(1), 139-152, http://doi.org/10.1017/s0003055404001054

Luhmann, N. (1988). Familiarity, Confidence, and Trust: Problems and Alternatives, in Gametta, D., ed., Trust: Making and Breaking Cooperative Relations. Oxford: Basil Blackwell

Luo, Y. (2005). An Organizational Perspective of Corruption. Management and Organization Review, 1(1), 119-154, https://doi.org/10.1111/j.1740-8784.2004.00006.x

Maddala, G. S. (1983). Limited Dependent and Qualitative Variables in Econometrics. Cambridge: Cambridge University Press. Online ISBN 9780511810176, http://doi.org/10.1017/cbo9780511810176 
Mauro, P. (1995). Corruption and Growth. The Quarterly Journal of Economics, 110(3), 681-712, August, http://doi.org/10.2307/2946696

Méon, P.-G., Sekkat, K. (2005). Does Corruption Grease or Sand the Wheels of Growth. Public Choice, January, 122(1), 69-97, http://doi.org/10.1007/s11127-005-3988-0

Mo, P. H. (2001). Corruption and Economic Growth. Journal of Comparative Economics, 29(1), 66-79, http://doi.org/10.1006/jcec.2000.1703

Montiel, I., Husted, B. W., Christmann, P. (2012). Using Private Management Standard Certification to Reduce Information Asymmetries in Corrupt Environments. Strategic Management Journal, 33(9), 1103-1113, http://doi.org/10.1002/smj.1957

Myrdal, G. (1968). Asian Drama: An Inquiry into the Poverty of Nations, Vol. II, New York: Pantheon.

North, D. C. (1990). Institutions, Institutional Change and Economic Performance. Cambridge: Cambridge University Press. Online ISBN 9780511808678, http://doi.org/10.1017/ cbo9780511808678

OECD (2005). Oslo Manual Proposed Guidelines for Collecting and Interpreting Technological Innovation Data, $3^{\text {rd }}$ Edition, Organisation for Economic Co-operation and Development, http://doi.org/10.1787/9789264013100-en

Paunov, C. (2016). Corruption's Asymmetric Impacts on Firm Innovation. Journal of Development Economics, 118, 216-231, http://doi.org/10.1016/j.jdeveco.2015.07.006

Pellegrini, L., Gerlagh, R. (2004). Corruption's Effect on Growth and its Transmission Chan-nels. KYKLOS, 57(3), 429-456, https://doi.org/10.1111/j.0023-5962.2004.00261.x

Pillay, S., Kluvers, R. (2014). An Institutional Theory Perspective on Corruption: The Case of a Developing Democracy. Financial Accountability \& Management, 30(1), 95-119, February, https://doi.org/10.1111/faam.12029

Rodriguez, P., Siegel, D. S., Hillman, A., Eden, L. (2006). Three Lenses on the Multinational Enterprise: Politics, Corruption, and Corporate Social Responsibility. Journal of International Business Studies, 37(6), 733-746, http://doi.org/10.1057/palgrave.jibs.8400229

Rose-Ackerman, S. (1975). The Economics of Corruption. Journal of Public Economics, 4(2), 187-203, http://doi.org/10.1016/0047-2727(75)90017-1

Rose-Ackerman, S. (1978). Corruption: A Study in Political Economy. New York: Academic, Ch. 5. ISBN 978-0125963503.

Rose Ackerman, S. (1999). Corruption and Government. Causes, Consequences and Reform. Cambridge: Cambridge University Press. Online ISBN 9781139175098, http://doi.org/10.1017/cbo9781139175098

Shaw, P., Katsaiti, M. S., Jurgilas, M. (2011). Corruption and Growth under Weak Identification. Economic Inquiry, 49(1), 264-275, January, http://doi.org/10.1111/j.1465-7295.2009.00276.x

Shleifer, A., Vishny, R. W. (1993). Corruption. Quarterly Journal of Economics, 108(3), 599-617, http://doi.org/10.2307/2118402

Stigler, G. J. (1971). The Theory of Economic Regulation. The Bell Journal of Economics and Management Science, 2(1), 3-21, http://doi.org/10.2307/3003160

Tanzi, V. (1995). Corruption, Arm's-Length Relationships, and Markets, in Fiorentini, G., Peltzman, S., ed., The Economics of Organised Crime. Cambridge: Cambridge University Press, http://dx.doi.org/10.1017/cbo9780511751882.014 
Tanzi, V. (1998). Corruption around the World: Causes, Consequences, Scope and Cures. International Monetary Fund. Working Paper, http://doi.org/10.5089/9781451848397.001

Thede, S., Gustafson, N. A. (2012). The Multifaceted Impact of Corruption on International Trade. The World Economy, 35(5), 651-666, http://doi.org/10.1111/j.1467-9701.2012.01436.x

Tomaszewski, M. (2015). Influence of Customer Pressure on the Innovative Activity of a Company. Argumenta Oeconomica, 2(35), 203-219

Tonoyan, V., Strohmeyer, R., Habib, M., Perlitz, M. (2010). Corruption and Entrepreneurship: How Formal and Informal Institutions Shape Small Firms Behavior in Transition and Mature Market Economies. Entrepreneurship Theory and Practice, 34(5), 803-831, http://doi.org/10.1111/j.1540-6520.2010.00394.x

Ugur, M. (2014). Corruption's Direct Effects on per Capita Income Growth: A Meta-Analysis. Journal of Economic Surveys, 28(3), 472-490, http://doi.org/10.1111/joes.12035

Ullah, B., Wei, Z. (2013). ISO Certification, Corruption and Firm Performance: A Cross-Country Study, Unpublished manuscript.

Vian, T., Brinkerhoff, D. W., Feeley, F. G., Salomon, M., Vien, N. T. K. (2012). Confronting Corruption in the Health Sector in Vietnam: Patterns and Prospects. Public Administration and Development, 32(1), 49-63, http://doi.org/10.1002/pad.1607

Villoria, M., Van Ryzin, G. G., Lavena, C. F. (2012). Social and Political Consequences of Administrative Corruption: A Study of Public Perceptions in Spain. Public Administration Review, 73(1), 85-94, http://doi.org/10.111/j.1540-6210.2012.02613.x

Williamson, O. E. (1991). Comparative Economic Organization: An Analysis of Discrete Structural Alternatives. Administrative Science Quarterly, 36(2), 269-296, http://doi.org/10.2307/2393356

Zaloznaya, M. (2015). Does Authoritarianism Breed Corruption? Reconsidering the Relationship between Authoritarian Governance and Corrupt Exchanges in Bureaucracies. Law \& Social Inquiry, 40(2), 345-376, http://doi.org/10.1111//si.12076

Zaloznaya, M. (2014). The Social Psychology of Corruption: Why It Does Not Exist and Why It Should. Sociology Compass, 8(2), 187-202, http://doi.org/10.1111/soc4.12120

http://ec.europa.eu/eurostat/statistics-explained/images/5/53/Gross_domestic_expenditure_ on_R\%26D\%2C_2003\%E2\%80\%9313_\%28\%25_of_GDP\%29_YB15.png;

http://knoema.com/UNESCOISD2014Aug/ unesco-institute-for-statistics-data-august-2014?location $=1000020$

http://www.enterprisesurveys.org/Methodology/ 